\title{
Hafnia paralvei ISOLATED FROM AN EMPHYSEMATOUS PYOMETRA IN A BITCH
}

\author{
Carlos A. Rodríguez-Alarcón', Jorge A. Leyva-Varela², Ricardo García-Herrera³, Miguel O. Montoya-Domínguez¹, Beatriz \\ Macías-García ${ }^{4}$, Diana M. Beristain ${ }^{1 *}$ \\ ${ }^{1}$ Veterinary Science Department, ${ }^{2}$ Resident of Small Animal Medicine and Surgery Speciality, Universidad Autónoma de Ciudad Juárez, \\ Juarez, ${ }^{3}$ Veterinary and Zootechny School, Universidad Juárez Autónoma de Tabasco, Villahermosa, Mexico, ${ }^{4}$ Veterinary Clinical Hospital \\ of the Faculty of Veterinary Medicine, Universidad de Extremadura, Cáceres, Spain.
}

${ }^{*}$ Corresponding author, E-mail: diana.beristain@uacj.mx [all authors contributed equally to the study and drafting of this paper]

\begin{abstract}
We report the case of a 9-year-old female Labrador retriever, presented to the Veterinary Teaching Hospital with a history of bloody/purulent and malodourous vulvar discharge, decreased appetite and progressive abdominal enlargement for about 20 days. Clinical examination showed a distended and painful abdomen and tympanic sounds on percussion. The patient also presented systemic inflammatory response syndrome (SIRS) and a leukemoid reaction with leukocyte count of $77.9 \times 10^{9} / \mathrm{L}$ due to $62.32 \times 10^{9} /$ Llymphocytes. The abdominal radiography showed distended tubular structures occupying most of the abdomen; dorsal displacement of the colon in the left-right lateral projection was also found. The ultrasonographic study also revealed tubular structures in the mid-abdomen that contained flowing fluid presenting mixed echogenicity and hyperechoic particles in suspension. The exploratory celiotomy showed that the uterine horns were distended and contained a mixture of gas and liquid, hence an ovariohysterectomy was performed. The uterine fluid was collected with aseptic technique into a syringe and submitted to the clinical pathology laboratory for aerobic and anaerobic culture and antibiotic sensitivity. Hafnia alvei (now classified as Hafnia paralvei) was identified as the causative bacterial agent. Pyometra caused by gas-producing bacteria is a rare condition and is known as emphysematous pyometra. There are only six reports in the literature of this condition in bitches. A wide range of vaginal bacteria has been found in dogs with pyometra, but to our knowledge this is the first report of emphysematous pyometra caused by Hafnia paralveiin dogs.
\end{abstract}

Key words: veterinary surgery; uterus; emphysematous pyometra; Hafnia paralvei

\section{Introduction}

Pyometra is a common condition that affects intact adult bitches in dioestrus (1). It is a local infection, but is often accompanied by sepsis and/ or systemic inflammatory response syndrome (SIRS) (2). Open cervix pyometra is most common, but the closed cervix pyometra have a poorer prognosis (3), and affects about $25 \%$ of old nulliparous bitches (4).

Received: 15 October 2018

Accepted for publication: 22 February 2019
Emphysematous pyometra is a rare entity, and has been described in only 6 reports $(5-10)$.

Although the most commonly isolated bacteria in dogs with pyometra is E. coli, several other bacteria found in the normal vaginal flora have been reported in canine pyometra (11-13).

Hafnia paralvei (formerly Hafnia alvei) is a gram-negative, mobile, rod-shaped facultative anaerobe. It is part of the normal microbiota of animals (14). In humans, it behaves as an opportunistic pathogen (15), but it is a rare cause of infection in humans and animals (1517). However, in veterinary medicine, it has been 
reported in equine abortion (18), as a secondary infection in a cat with a nasal tumor (19), and was also isolated from the wound of a dog (20).

In the past, the genus consisted of a single species, Hafnia alvei. However, in 2010, organisms previously called Hafnia alvei HG 2 were categorized as a novel species, Hafnia paralvei (21).

The objetive of this study is to present a rare case of an emphysematous pyometra in a bitch, in which was isolated Hafnia paralvei.

\section{Case}

A 9-year-old Labrador retriever nulliparous bitch was submitted to our hospital for evaluation. The animal had a history of vaginal bleeding and a purulent and foul-smelling vulvar discharge. The owner reported that the patient had been hyporexic and that the abdomen had progressively increased in size. The animal weighed $25.36 \mathrm{~kg}$ and the last heat had occurred 2 months before.

The clinical evaluation revealed a heart rate of 120 beats per minute, respiratory rate of 40 breaths per minute, and a dehydration rate of $7 \%$, with pale mucous membranes, delayed capillary refill time $(>3$ seconds) and a temperature of $40^{\circ} \mathrm{C}$. Moreover, the patient showed abdominal pain on palpation and tympanic sound on percussion. In addition, the bloody-purulent vulvar discharge was confirmed.

Theabdominalleft-rightlateralandventro-dorsal projection showed distended tubular structures occupying most of the abdomen (Figure 1). The presence of coprolites was confirmed in both projections.

The abdominal ultrasonography showed tubular structures in the mid-abdomen presenting mixed echogenicity; a flow of hyperechoic particles in suspension and reverberation lines superimposed on the image of mixed echogenicity were also found.

The complete blood count (CBC) findings showed a decrease in hemoglobin values $7.1 \mathrm{~g} /$ dl (range 12-18 g/dl), hematocrit $0.204 \mathrm{~L} / \mathrm{L}$ (range 0.37-0.55 L/L), erythrocytes $3.53 \times 10^{12} / \mathrm{L}$ (range 5.5-8.5 $\times 10^{12} / \mathrm{L}$ ) and platelets $160 \times 10^{9} / \mathrm{L}$ (range $175-500 \times 10^{9} / \mathrm{L}$ ). The mean corpuscular hemoglobin (MCH) $34.9 \mathrm{~g} / \mathrm{dl}$ (range 31-37 g/dl) and mean corpuscular volume (MCV) $57.9 \mathrm{FL}$ (range 60-72 FL) were within normal ranges. The patient also presented a highly elevated leukocyte count of $77.9 \times 10^{9} / \mathrm{L}$ (range $5.5-16.9 \times 10^{9} / 1$ ), with $62.32 \times 10^{9} / \mathrm{L}$ lymphocytes (ranges $1-4.9 \times 10^{9} / \mathrm{L}$ ).
Based on the imaging and laboratory findings we conducted an exploratory celiotomy with a presumptive diagnosis of emphysematous pyometra. The preanaesthetic medication protocol was an intravenous dose of the commercial combination of tiletamine/zolazepam (5 mg/ kg) (Zelatol, Fort Dodge, Spain) plus tramadol (3 mg/kg, IV) (Tramadol Jet, Norvet, Mexico) for analgesia. For the induction of anaesthesia an intravenous dose $(4 \mathrm{mg} / \mathrm{kg}$ ) of propofol (Fresofol, Fresenius Kabi, Austria) was used. The inhalant anaesthesia was maintained with $2.5 \%$ inspired fraction of isoflurane.

Exploratory celiotomy confirmed the presence of distended uterine horns containing gas and fluid (Figure 2), therefore ovariohysterectomy was performed. Further pre- and postoperative medication included cefazolin (25 mg/kg, IV) (Cefazolin, Apotex Corp, USA), q12 h, gentamicine (6 mg/kg, IV, q 24 h) (Genta Ved, Vedco, USA), metronidazole (15 mg/kg, IV, q 12 h) (Flagyl, Sanofi, Mexico), tramadol (3 mg/kg, IV, q $12 \mathrm{~h}$ ) and carprofen (2 mg/kg, PO, q $24 \mathrm{~h}$ for 7 days) (Novox, Vedco, USA).

Uterine and ovarian tissue samples were submitted to the histopathology laboratory. The histopathological report revealed cystic endometrial hyperplasia and suppurative metritis/endometriosis. Fluid from the uterus was collected via aseptic technique into a syringe, air was removed and the syringe was sealed. The sterile sample was sent to the clinical pathology laboratory for aerobic and anaerobic culture and antibiotic sensitivity. Hafnia paralvei was recovered in pure culture of the uterine fluid.

Two days after surgery, the patient was discharged with oral cephalexin $(22 \mathrm{mg} / \mathrm{kg}$, $\mathrm{PO}$, q 12 h) (Ceporex, Glaxo Smithkline, Mexico) metronidazole (15 mg/kg, IV, q $12 \mathrm{~h}$ ), and tramadol (5 mg/kg, PO, q 12 h).

The patient recovered completely within a week. Laboratory control tests were taken, being all the biochemical and haematological results within the normal range.

\section{Discussion}

Canine pyometra is a common disease of intact bitches; with previous reviews indicating that approximately $75 \%$ of bitches with pyometra are nulliparous. A delay in onset of treatment of this condition may result in toxaemia, septicaemia 
Figure 1: A) Left-right lateral and B) Dorsal-ventral view of the abdomen of a 9-year-old Labrador retriever bitch with emphysematous pyometra. Notice the large tubular structure filled with gas displaced to the ventral side, the presence of coprolites, and complete and incomplete spondylosis deformans from $\mathrm{T}-10$ to L-4

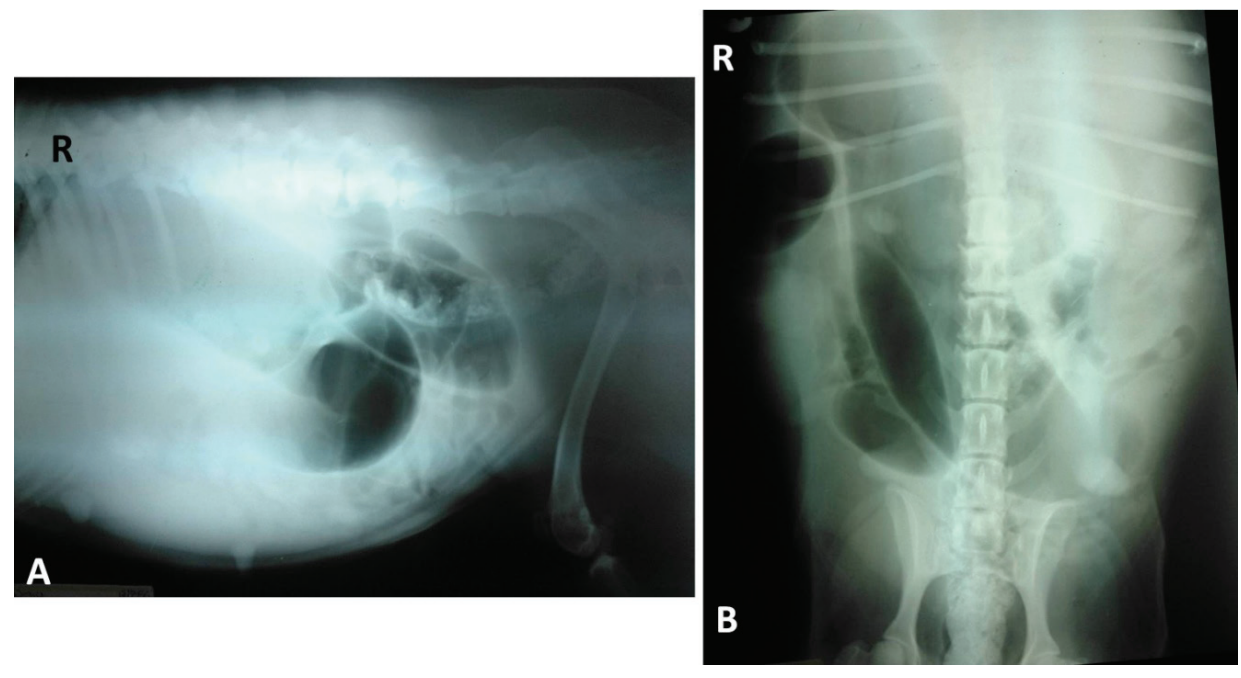

Figure 2: A 9 year old Labrador Retriever bitch with emphysematous pyometra. Notice the uterus filled with gas and liquid on the inside

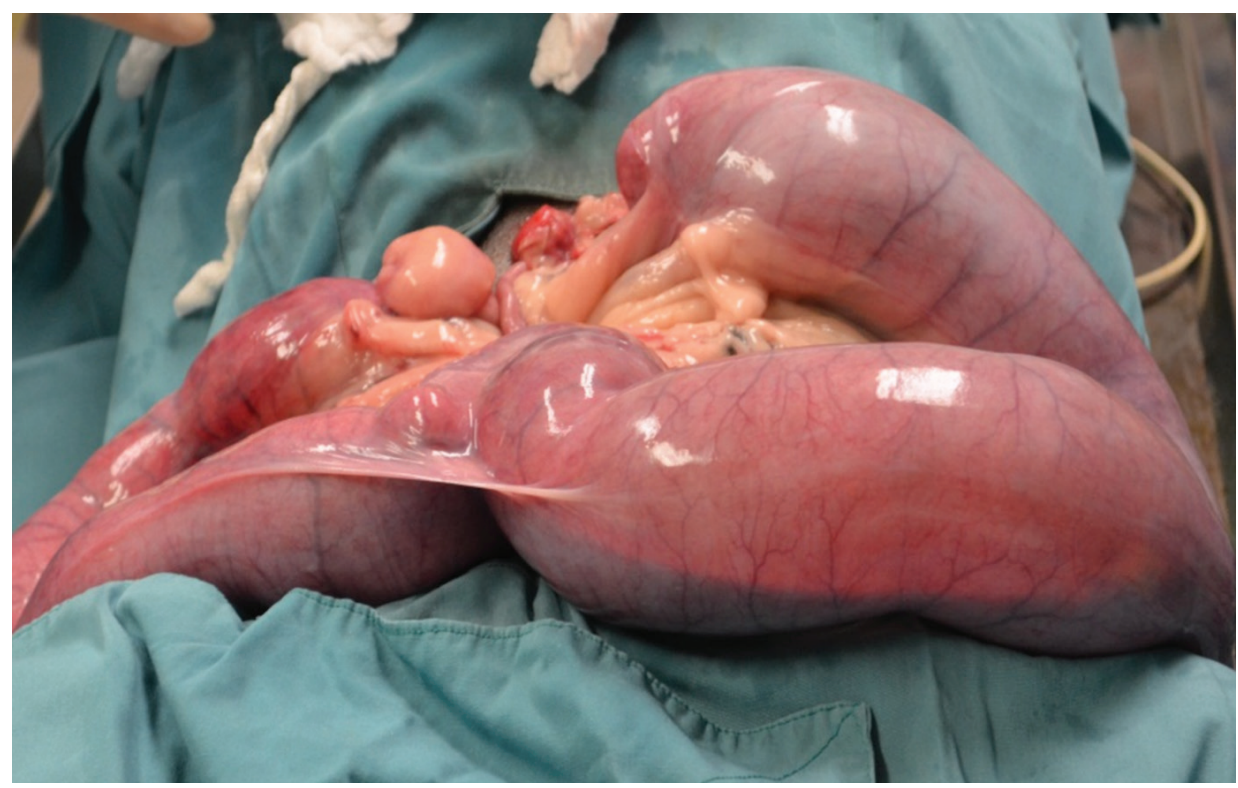

and even death of the patient. This condition is more common in older bitches (average age of 7.25 years) (22). Pyometra usually occurs during dioestrus, except when the infection progresses slowly, and dioestrus ends before the diagnosis is confirmed (23). The history and clinical findings in our case matches those commonly described in canine pyometra: age, breed, nulliparity and the resumption of oestrus 2 months prior to the onset of the disease.

The physical examination and laboratory results suggested SIRS in this dog, which has previously been described in $57 \%$ of bitches with pyometra, causing the production and release of inflammatory mediators (2). Patients with SIRS can be identified when presenting at least two of the following four criteria: heart rate greater than 160 beats per minute, temperature greater than $39.7^{\circ} \mathrm{C}$ or less than $37.7^{\circ} \mathrm{C}$, respiratory rate over20 breaths per minute or a carbon dioxide pressure lower than $32 \mathrm{~mm} / \mathrm{Hg}$, and a WBC count over $12.000 / \mu 1$ or below $4,000 / \mu 1$ or more than $10 \%$ of band neutrophils (24). Our patient matched three of these parameters: temperature of $40^{\circ} \mathrm{C}, 40$ breaths per minute and a leukocytosis of $77,000 / \mu 1$. This markedly high leukocyte count is known as leukemoid reaction; this condition has been described in canine pyometra. In the same form that another inflammatory conditions, pyometra stimulating the formation of cytokines 
such granulocyte colony stimulating factor and granulocyte/macrophage colony stimulanting factor. This cytokines, stimulating granulopoiesis because promote release of neutophils in the bone marrow (25). In acute cases, a myeloid leukemoid reaction with neutrophilia and toxic neutrophils has been described (26), although this was not the scenario found in our case. In the present case, the bitch presented an uncommon lymphoid leukemoid reaction.

Although the most common bacterial agent associated with pyometra in bitches is E. coli, several aerobic and anaerobic bacteria have been reported to be involved (10-13). Pyometra caused by gas-producing bacteria is a very rare condition and is also known as emphysematous pyometra. This condition has only been described six times in the literature (5-10). Therefore, this is the first report of an emphysematous pyometra caused by Hafnia paralvei, a gram-negative, mobile, facultative aerobe bacillus capable of producing gas (27). Other studies have isolated different vaginal bacteria in healthy dogs, but in none of them Hafnia paralvei was identified $(28,29)$. It is the only species of Hafnia in the Enterobacteriaceae family. This bacterium is widely distributed in water, soil and food and is also part of the normal intestinal microbiota of mammals, marsupials, birds, reptiles, fish, invertebrates and insects (15, $30,31)$. In humans, it is described as an unusual opportunistic pathogen causing nosocomial (18) or community infections $(32,33)$. This bacterium is not a common pathogen in animals (15), although it has been isolated in some cases $(18-20,34)$, but never has been isolated from a pyometra.

In the majority of bitches that develop pyometra, vaginal contamination is the source of infection (35). However, a previous report showed a strong correlation between the normal canine intestinal bacteria and those found in the uterus of dogs with pyometra (36). Although we did not perform faecal culture in this animal, we suspect that the bacteria arrived to the uterus via ascendent faecal contamination, as previously described for other causative agents of pyometra (37).

We conclude that, even though emphysematous pyometra is uncommon in dogs, it should be regarded as a presumptive diagnosis in patients presenting with tubular structures filled with gas in abdominal radiographs, especially in bitches with vulvar discharge presented during dioestrus. Finally, in the present clinical report we describe for the first time a case of canine emphysematous pyometra caused by Hafnia paralvei.

\section{Acknowledgement}

Beatriz Macias Garcia is funded by a Ramón y Cajal grant from the Spanish Ministry of Science, Innovation and Universities (RYC-2017-21545; AEI/FEDER/UE).

\section{References}

1. Qian C, Hou J. Escherichia coli virulence influences the roles of sex hormone receptors in female dogs with simulated pyometra. Exp Ther Med 2017; 14: 3013-21.

2. Fransson B, Lagerstedt A, Bergstrom A, et al. C-reactive protein, tumor necrosis factor $a$, and interleukin-6 in dogs with pyometra and SIRS. J Vet Emerg Critl Care 2007; 17: 373-81.

3. Pretzer S. Clinical presentation of canine pyometra and mucometra: a review. Theriogenology 2008; 70: 359-63.

4. Hagman R, Lagerstedt A, Hedhammar Å, et al. A breed-matched case-control study of potential risk-factors for canine pyometra. Theriogenology $2011 ; 75$ : 1251-57.

5. Jameson C. Emphysematous pyometra in a bitch. J Am Vet Med Assoc 1982; 181: 388.

6. Hernandez J, Besso J, Rault D, et al. Emphysematous pyometra in a dog. Vet. Radiol U1trasound 2003; 44(2): 196-8.

7. Thilagar S, Vinita $\mathrm{W}$, Heng $\mathrm{H}$, et al. What is your diagnosis? Small intestinal and colonic obstruction: emphysematous piometra. J Small Anim Pract 2006; 47: 687-8.

8. Chang J, Jung J, Jeong Y, et al. Citrobacter emphysematous pyometra in a dog. J Small Anim Pract 2011; 48(12): 717-9.

9. Gomes L, Martins M, Shimozaka N, et al. Piometra enfisematosa em cadela. Semina Ciênc Agrár 2011; 32(3): 1133-8.

10. Chang AC, Cheng CC, Wang H. C, et al. Emphysematous pyometra secondary to Enterococcus avium infection in a dog. Tierärztl Prax K 2016; 44(3): 195-9.

11. Lee S, Cho J, Shin N, et al. Identification and antimicrobial susceptibility of bacteria from the uterus of bitches with pyometra. Korean J Vet Res 2000; 40: 763-7.

12. Lee C, Wu F, Liu P. A retrospective study 
on canine pyometra and hydrometra in central Taiwan. Taiwan Vet J 2006; 32: 17-3.

13. Zduńczyk S, Janowsky T, Borkowska I. Vaginal and uterine bacterial flora in bitches with physiological and inflammatory conditions. Med Wet 2006; 62: 116-9.

14. Janda J, Abbott S. The genus Hafnia: from soup to nuts. Clin Microbiol Rev 2006; 19(1): 12-7.

15. Padilla D, Acosta F, Ramos-Vivas J, et al. The pathogen Hafnia alvei in veterinary medicine: a review. J Appl Anim Res 2015; 43: 231-5.

16. Moreno C, Troncoso M, De La PC, et al. Report of four clinical cases of Hafnia alvei bacteremia in a pediatric cardiac surgery unit. Chilean Infect J 2010; 27(1): 40-4.

17. Kaakoush N, Quinlivan J, Mendz G. Bacteroides and Hafnia infections associated with chorioamnionitis and preterm birth. J Clin Gynecol Obstet 2014; 3: 76-9.

18. Rojas X, Orielc A. Hafnia alvei in an isolated equine abortion case. Vet Med Arch 1983; 15(2): 90-1.

19. Julian M, Paludi A, Del Sole M. Feline unilateral mydriasis as the only sign of intranasal neoplasia. Medicina-felina.com.ar http://www. medicina-felina.com.ar/articulos/para-profesionales/midriasis-unilateral-feli (14. Oct. 2018)

20. 20. Ishii J, Freitas J, Arias M. Resistance of bacteria isolated from dogs and cats at Veterinary Hospital of Universida de Estadual de Londrina (2008-2009). Pesq Vet Bras 2011; 31(6): 533-7.

21. Huys G, Cnockaert M, Abbott SL, Janda JM, Vandamme P. Hafnia paralvei sp. nov., formerly known as Hafnia alvei hybridization group 2. Int J Syst Evol Microbiol 2010; 60: 1725-8.

22. Prasad VD, Kumar PR, Sreenu M. Pyometra in bitches: a review of literature. Res Rev J Vet Sci Technol 2017; 6: 12-20.

23. Bergstrom A. Pyometra and cyst endometrial. In: Ettinger S, Feldman E, Coté E, eds. Textbook of veterinary internal medicine disease of the dog and cat. 5th ed. St. Louis : WB Saunders, 2017: 1878-3.

24. Purvis D, Kirby R. Systemic inflammatory response syndrome: septic shock. Vet Clin North Am Small Anim Pract 1994; 24: 1225-47.

25. Han JI, Jang HJ, Jun KH. et al. Extreme leukemoid reaction in a dog with pyometra. J Vet Clin 2009; 26: 619-21.
26. Schultze A. Interpretation of canine leukocytes response. In: Weiss DJ, Wardrob KJ, eds Schalm's veterinary hematology. 6th ed. Ames : Wiley-Blackwell, 2010: 323.

27. Romero C. Human microbiology and parasitology. 3rd ed. México: Panamericana, 2007

28. Gao X, Zhou L, Deng G, et al. Aerobes and levels of estradiol and progesterone in cystic endometrial hyperplasia-pyometra complex bitches. J Anim Vet Adv 2011; 10: 965-71.

29. Groppetti D, Pecile A, Barbero C, et al. Vaginal bacterial flora and cytology in proestrous bitches: role on fertility. Theriogenology 2012; 77 : 1549-56.

30. Giinthard H, Pennekamp A. Clinical significance of extraintestinal Hafnia alvei isolates from 61 patients and review of the literature. Clin Infect Dis 1996; 22: 1040-45.

31. Madec J, Lazizzera C, Châtre $P$, et al. Prevalence of fecal carriage of acquired expanded-spectrum cephalosporin resistance in Enterobacteriaceae strains from cattle in France. J Clin Microbiol 2008; 46(4): 1566-7.

32. Karamanl H, Özer TT. A rare case of Hafnia alvei pneumonia presenting with chronic obstructive pulmonary disease. Turk Gogus Kalp Dama 2017; 25: 308-11.

33. Nayak N, Baral N, Shrestha R, et al. Hafnia alvei bacteremia following bronchopneumonia in an eleven month old child: a case report from a tertiary care hospital in Nepal. Int J Adv Life Sci Res 2018; 1: 34-43.

34. 34. Mukherjee SR, Das AM, Paranjape VL, Marwah SR. Hafnia alvei isolated from an equine aborted foetus. Indian J Anim Sci 1986; 6: 101-2.

35. Kitshoff A, Van Goethem B, Boyen F, Tas $\mathrm{O}$, Polis I, De Rooster H. Clinical parameters as predictors of bacterial isolation in the uterine content of dogs suspected of pyometra. Vlaams Diergeneeskd Tijdschr 2015; 84: 188-96.

36. Hagman R. Pyometra in small animals. Vet Clin North Am Small Anim Pract 2018; 48: 639-61.

37. Fransson B, Ragle C. Canine pyometra: an update on pathogenesis and treatment. Compend Contin Educ Pract Vet 2003; 25: 602-11. 


\title{
Hafnia paralvei IZOLIRANA IZ EMFIZEMAZOTNE PIOMETRE PRI PSICI
}

\author{
C. A. Rodríguez-Alarcón, J. A. Leyva-Varela, R. García-Herrera, M. O. Montoya-Domínguez, B. Macías-García, D. M. Beristain
}

Povzetek: Včlanku poročamo o primeru 9-letne samice pasme labradorec, ki je bil sprejet vBolnišnici za veterinarsko medicino z anamnezo gnojnih in smrdljivih izločkov iz vulve, zmanjšanim apetitom in postopnim povečevanjem trebuha, kar je trajalo približno 20 dni pred obiskom veterinarja. Klinični pregled je pokazal napihnjen in boleč trebuh in timpanične zvoke ob pretrkavanju. Pacientka je imela tudi sindrom sistemskega vnetnega odziva (SIRS) in povečano skupno število levkocitov (77.9 x 109/L) zaradi povišanega števila limfocitov (62.32 × 10\%/L). Rentgenska slika trebuha je pokazala razširjene cevaste strukture, ki so zasedale večino trebuha; na stranski projekciji (levo-desno) pa so ugotovili tudi dorzalni premik debelega črevesa. Ultrazvočni pregled je prav tako pokazal cevaste strukture v sredini trebuha, ki so vsebovale tekočino mešane ehogenosti s hiperehoičnimi delci v suspenziji. Preiskovalna celiotomija je pokazala, da so bili rogovi maternice raztegnjeni in so vsebovali mešanico plina in tekočine, zato je bila izvedena ovariohisterektomija. Tekočino iz maternice so z aseptično tehniko zbrali v injekcijsko brizgo in jo predali kliničnemu patološkemu laboratoriju za ugotavljanje prisotnosti aerobnih in anaerobnih bakterij ter bakterijske občutljivosti na antibiotike. Hafnio alvei (sedaj razvrščeno kot Hafnia paralvei) so opredelili kot bakterijskega povzročitelja piometre. Piometra, ki jo povzročajo bakterije, ki proizvajajo plin, je redko stanje in je znana kot emfizematozna piometra. V literaturi je opisanih le šest primerov pri psicah. Pri psicah s piometro so našli širok spekter vaginalnih bakterij, vendar je to prvo poročilo o emfizematozni piometri, ki jo povzroča Hafnia paralveipri psicah.

Ključne besede: veterinary surgery; uterus; emphysematous pyometra; Hafnia paralvei 